\title{
Status of Gastrointestinal Nematode Infections and Associated Epidemiological Factors in Sheep From Córdoba, Colombia
}

\author{
Elisa Brunal Tachack \\ Universidad de Cordoba \\ Teresa Oviedo-Socarrás \\ Universidad de Cordoba \\ Misael Oviedo Pastrana \\ Corporacion Colombiana de Investigación Agropecuaria: AGROSAVIA \\ Luis Carlos Pérez-Cogollo ( $\square$ luisperez@correo.unicordoba.edu.co) \\ Universidad de Córdoba https://orcid.org/0000-0003-0685-4667 \\ Yonairo Herrera Benavides \\ Universidad de Cordoba \\ Clara Rugeles Pinto \\ Universidad de Cordoba \\ Oscar Vergara Garay \\ Universidad de Cordoba
}

\section{Research Article}

Keywords: Helminthiasis, epidemiology, parasite burden, ovine, Colombia

Posted Date: August 19th, 2021

DOI: https://doi.org/10.21203/rs.3.rs-726472/v1

License: (c) (1) This work is licensed under a Creative Commons Attribution 4.0 International License. Read Full License 


\section{Abstract}

Gastrointestinal nematodes cause serious economic losses in sheep production systems. To determine the prevalence and risk factors associated with these parasites, a study was conducted in 595 sheep in Córdoba, Colombia. Prevalence and parasite burden were determined using the McMaster technique. Larvae were cultured from feces to identify the nematode genera. For the analysis of associated factors and parasite burden, means, medians and confidence intervals were compared. A geo-referenced data analysis was performed and an epidemiological map was constructed. An overall prevalence of $88.2 \%$ was found, with the highest prevalence and parasite burden for Strongylida (83.2\%) and Strongyloides (41\%) nematodes. The mean parasite burden was 1255 eggs per gram. The gastrointestinal nematode genera identified were Trichostrongy/us, Strongyloides, Haemonchus, Oesophagostomum, Bunostomum and Cooperia. In general, a significant association was found between parasite burden and dewormed animals, anthelmintic used, date of last deworming and breeds. The FAMACHA® method and body condition showed a significant association with Strongylida parasite burden. Clusters with higher intensity of gastrointestinal nematode burden and high prevalence were observed in the regions of Bajo Sinú, Sinú Medio and San Jorge.

\section{Introduction}

Sheep are a susceptible species to multiple gastrointestinal nematode infections (GIN). Infections can be associated with several factors such as the age of the animal, the breed, the parasite species involved and the degree of parasitic infection, among others (Al-shaibani et al. 2008); these can alter animal welfare and, therefore, the productive levels of farms, regardless of the farming system (Herrera et al. 2013).

GIN cause a major health and economic impact on extensive livestock production due to reduced weight gain, mortality, and the high costs of anthelmintic treatments used for their control. Additionally, the emergence of GIN populations resistant to all anthelmintic families available in the Americas makes the control of these parasites even more difficult (Kaplan 2020).

Parasitic gastroenteritis is a multi-etiological disease, however, the GIN responsible for sheep deaths belongs mainly to the order Strongylida, superfamily Strongyloidea (Zajac and Garza 2020). Among these, the genera Haemonchus, Trichostrongylus, Teladorsagia (Ostertagia) and Oesophagostomum are the most frequent (Torres-Acosta et al. 2012; Herrera et al. 2013). Other GIN belonging to different taxonomic orders commonly parasitize sheep in the Americas and include Strongyloides, Aoncotheca (formerly Capillaria), Trichuris and Skrjabinema. Although these nematodes are not considered to be of major pathogenic importance and cause disease only in unusual circumstances (Zajac and Garza 2020).

In Colombia, studies on parasitic gastroenteritis have revealed the prevalence of endoparasites in different areas and climates involved in sheep farming (Ensuncho et al. 2014; Pulido et al. 2014). In the department of Córdoba, frequency studies of gastrointestinal parasites in sheep have been conducted (Ensuncho et al. 2014); however, there is no knowledge about the factors associated with gastrointestinal parasitism in sheep farms present in all its regions.

For the rational and sustainable control of gastrointestinal parasitism in sheep, a thorough knowledge of the epidemiology of the parasites and their interaction with the host in a specific environment is required (Keyyu et al. 2005). Therefore, knowledge of the parasite species found in a specific region, their prevalence, the degree of infection, the characteristics of the local climate, the size of the flocks and the cultural practices carried out there, among others, are essential (Kaplan and Vidyashankar 2012). For this reason, the objective of this study was to determine the prevalence and risk factors associated with gastrointestinal parasitism in sheep from the department of Córdoba-Colombia.

\section{Materials And Methods}

Study area The study was carried out in the department of Córdoba, which is divided into six regions, as follows: Alto Sinú, Sinú Medio, Bajo Sinú, Sabanas, San Jorge and Costanera. The department's climate can be divided into four areas. The first corresponds to the northern or coastal area, with rainfall of no more than $800 \mathrm{~mm}$ and a temperature of no less than $28^{\circ} \mathrm{C}$. The second section is defined by the valleys, with rainfall between 1,000 and $2,000 \mathrm{~mm}$; the third corresponds to the south of the department, with an annual rainfall of more than 2,000 mm; and finally, the foothills of the mountain range with temperatures of 18 to $24^{\circ} \mathrm{C}$ and rainfall of more than $3,000 \mathrm{~mm}$ per year. On average, it has an altitude of $30 \mathrm{~m}$.a.s.l., an annual temperature of $28^{\circ} \mathrm{C}$ and relative humidity that varies between 80 and $87 \%$. It belongs to the tropical rainforest climate formation and during the year there is a rainy period (May to November) and a dry period (December to April).

Study design A descriptive cross-sectional study was carried out to determine the prevalence of GIN in sheep from the department of Córdoba and associated factors. To determine the sample size, an infinite population of sheep, $75 \%$ estimated true prevalence, $80 \%$ sensitivity and $90 \%$ diagnostic specificity, a precision of $6 \%$ and a confidence level of $95 \%$ were assumed. The calculation determined a sample size of 511 sheep. In the end, 595 sheep were sampled in 60 farms.

The study was conducted over a 12-month period. Two farms were evaluated in each of the 30 municipalities of the department of Córdoba, distributed in the six geographical regions of the department. On each farm, one breeding male, three breeding females, two rearing females and two rearing males, and one lamb from each sex were sampled. The animals sampled in each farm were randomly selected. 
Sample and data collection Fecal samples were taken directly from the rectum using polyethylene gloves and blood samples were taken from the jugular vein using vacutainer tubes with an anticoagulant. The samples were identified with consecutive alphanumeric codes and kept refrigerated at $4^{\circ} \mathrm{C}$ until processing.

In addition, a clinical examination was performed on each animal, recording the aspects of the breed, sex, age, productive stage, weight, assessment of ocular conjunctival coloration by FAMACHA® method and assessment of body condition. An epidemiological survey on aspects related to the management and control of gastrointestinal parasites in the flock was conducted with each producer. The geographic coordinates of each farm were determined by Global Positioning System (GPS).

Laboratory testing To determine the GIN burden in each animal, the McMaster technique was applied, using McMaster chambers with two fields (Chalex Corporation ${ }^{\circledR}$ ) and a conversion factor of 50 suggested by the commercial company for the calculation of eggs per gram (EPG) of fecal matter.

For the identification and counting of the nematode genera present in each farm, a pool was made of all the coprological samples obtained in the farm, $10 \mathrm{~g}$ of this pool were used to perform a faecal culture for the recovery of infective larvae of GIN (L3) using the technique of Corticelli and Lai (1963). Larvae were identified by microscopy using taxonomic keys based on their morphology: total size, tail size and shape of the sheath; size and shape of the esophagus; number and shape of intestinal cells and refractile bodies (Van Wyk et al. 2004).

Data analyses The prevalence of GIN in each farm and in sheep population was determined in the department of Córdoba. The parasitic burden of each animal (EPG) and the average parasitic burden in each farm were also determined. For the analysis of risk factors associated with the parasitic burden, means, medians and confidence intervals were compared; the Kruskal-Wallis test was applied with a significance level of $5 \%$; the statistical program Epilnfo, version 7.2.2.2.2 was used. Finally, areas with the highest concentration of parasite burdens were identified using the kernel density estimator; the georeferenced data were analyzed and an epidemiological map was constructed using standard deviation on the mean in the categorization of the data and a bandwidth of $25 \mathrm{~km}$. The QGIS program, version 3.4, was used for this purpose.

\section{Results}

\section{Prevalence and parasite burden}

According to the results, $88.2 \%$ of the animals were positive for one or more groups of parasites; $83.2 \%$ were positive for nematodes of the order Strongylida, $41.0 \%$ for Strongyloides spp. and 2.2\% for Trichuris spp. (Table 1); at farm scale, the prevalence was $100 \%$. Overall parasite burden showed an average count of 1255 EPG; the Strongylida order showed the highest average parasite burden (943 EPG), followed by Strongyloides spp. and Trichuris spp. with low average parasite burdens (Table 1). Multiple parasitic infections were frequently observed in the animals under study. The main associations were between Strongylida and Strongyloides spp. The composition of GIN infections is presented in Table 2.

Table 1

Prevalence of gastrointestinal nematode infections and parasite burdens in sheep in the department of Córdoba.

\begin{tabular}{|lllllll|}
\hline Variable & $\mathbf{n}$ & Prev. (\%) & EPG mean & Inf. & Sup. & Sd \\
\hline Strongylida & 595 & 83,2 & 943 & 806 & 1079 & 1698 \\
\hline Strongyloides spp. & 595 & 41,0 & 311 & 227 & 395 & 1043 \\
\hline Trichuris spp. & 595 & 2,2 & 2 & 1 & 3 & 13 \\
\hline Overall count & 595 & 88,2 & 1255 & 1093 & 1418 & 2021 \\
\hline n: Sampled animals; Prev.: Prevalence; EPG: Eggs Per Gram; Inf.: Lower limit; Sup.; Upper limit; Sd: Standard deviation. \\
\hline
\end{tabular}


Table 2

Gastrointestinal nematode infection and co-infection in sheep in the department of Córdoba.

\begin{tabular}{|c|c|c|c|c|c|}
\hline \multirow[t]{3}{*}{ Parasite } & \multicolumn{4}{|c|}{ Multiple infections } & \multirow[t]{3}{*}{ Negatives } \\
\hline & I & II & & III & \\
\hline & & $\begin{array}{l}\text { Strongyloides } \\
\text { spp. }\end{array}$ & Trichuris spp. & Strongyloides spp. Trichuris spp. & \\
\hline Strongylida & 276 & 206 & 5 & 8 & \\
\hline Strongyloides spp. & 30 & - & - & - & 70 \\
\hline Trichuris spp. & 0 & - & - & - & \\
\hline \multirow[t]{2}{*}{ TOTAL } & 306 & 211 & & 8 & 70 \\
\hline & $(51.40 \%)$ & $(35.50 \%)$ & & $(1.30 \%)$ & $(11.80 \%)$ \\
\hline
\end{tabular}

I: Animals infected with one type of nematode; II: Animals co-infected with two types of nematodes; III: Animals co-infected with three types of nematodes.

\section{Predisposing Factors Associated With Gin Burden In Sheep}

Several variables were analyzed to see their relations with the parasitic burden of the sheep studied, among them: deworming, anthelmintic used, the time elapsed since the last deworming, sex, productive stage and breed. The breeds were grouped as Ovinos de Pelo Criollo Colombiano (OPC) among which were found: Criollo, Chino Rojo, Sudan and Abisinio, and breeds not belonging to Ovinos de Pelo Criollo (Non-OPC), among them: Katahdin, Santa Inés, Pelibuey, Black Belly, Dorper, Persian, White Dorper and some crossbreeds with OPC. The association of the different variables was made with the overall parasitic burden and with the burden of each type of nematode.

Overall, an association was found between the parasitic burden and the variables: dewormed animal, anthelmintic used, last deworming and breed. (Table 3). In terms of nematode types, the parasite burden of the order Strongylida was significantly associated with dewormed animal, anthelmintic used, the time elapsed since the last deworming and breed. For Strongyloides spp., an association was identified with the variables dewormed animal, time since the last deworming and productive stage; in the case of Trichuris spp., an association was only found with the productive stage of the animal (Table 4). 
Table 3

Factors associated with overall gastrointestinal nematode burden in sheep in the department of Córdoba, Colombia.

\begin{tabular}{|c|c|c|c|c|c|c|c|}
\hline Variable & Category & Sample size & Pos & $\begin{array}{l}\text { Mean } \\
\text { (EPG) }\end{array}$ & Sd. & Med. & p-value \\
\hline \multirow[t]{2}{*}{ Dewormed animal } & Yes & 298 & 269 & 1583 & 2459 & 700 & \multirow[t]{2}{*}{0,0002} \\
\hline & No & 297 & 257 & 926 & 1382 & 450 & \\
\hline \multirow[t]{4}{*}{ Anthelmintic used } & Fenbendazole & 207 & 190 & 1677 & 2525 & 900 & \multirow[t]{4}{*}{0,0485} \\
\hline & Ivermectin & 28 & 27 & 2530 & 3595 & 800 & \\
\hline & Levamisole & 54 & 43 & 881 & 1158 & 500 & \\
\hline & Natural med. & 8 & 8 & 669 & 476 & 550 & \\
\hline \multirow[t]{3}{*}{ Last deworming } & $<45$ days & 138 & 122 & 1879 & 2839 & 800 & \multirow[t]{3}{*}{0,0007} \\
\hline & $46-120$ days & 160 & 147 & 1328 & 2052 & 600 & \\
\hline & $>120$ & 297 & 257 & 926 & 1382 & 450 & \\
\hline \multirow[t]{2}{*}{ Sex } & Female & 368 & 325 & 1170 & 1860 & 525 & \multirow[t]{2}{*}{0,204} \\
\hline & Male & 227 & 201 & 1392 & 2255 & 650 & \\
\hline \multirow[t]{6}{*}{ Productive stage } & Lambs & 134 & 112 & 1349 & 2576 & 500 & \multirow[t]{6}{*}{0,0750} \\
\hline & Rearing lambs & 201 & 183 & 1403 & 2114 & 700 & \\
\hline & Pregnant ewes & 64 & 59 & 670 & 728 & 400 & \\
\hline & Lactating ewes & 98 & 87 & 1472 & 1925 & 725 & \\
\hline & Empty ewes & 33 & 29 & 932 & 1233 & 400 & \\
\hline & Breeding male & 65 & 56 & 1019 & 1620 & 500 & \\
\hline \multirow[t]{2}{*}{ Breed } & OPC & 292 & 261 & 949 & 1210 & 525 & \multirow[t]{2}{*}{0,0478} \\
\hline & Non OPC & 303 & 265 & 1550 & 2538 & 650 & \\
\hline
\end{tabular}

Pos: Positives; EPG: Eggs per gram; Sd: Standard deviation; Natural Med.: Use of medicinal plants; OPC Ovinos de Pelo Criollo; Med.: Median. 
Table 4

Factors associated with Strongylida, Strongyloides spp. and Trichuris spp. burdens in sheep in the department of Córdoba.

\begin{tabular}{|c|c|c|c|c|c|c|c|c|c|c|c|c|c|c|}
\hline \multirow[t]{2}{*}{ Variable } & \multirow[t]{2}{*}{ Category } & \multirow[t]{2}{*}{$\mathrm{n}$} & \multicolumn{4}{|c|}{ Strongylida } & \multicolumn{4}{|c|}{ Strongyloides spp } & \multicolumn{4}{|c|}{ Trichuris spp } \\
\hline & & & Pos. & $\begin{array}{l}\text { Mean } \\
\text { (EPG) }\end{array}$ & $\begin{array}{l}\text { Med. } \\
\text { (EPG) }\end{array}$ & $\begin{array}{l}\mathrm{p}- \\
\text { value }\end{array}$ & Pos. & $\begin{array}{l}\text { Mean } \\
\text { (EPG) }\end{array}$ & $\begin{array}{l}\text { Med. } \\
\text { (EPG) }\end{array}$ & $\begin{array}{l}\mathrm{p}- \\
\text { value }\end{array}$ & Pos. & $\begin{array}{l}\text { Mean } \\
(E P G)\end{array}$ & $\begin{array}{l}\text { Med. } \\
\text { (EPG) }\end{array}$ & $\begin{array}{l}\mathrm{p}- \\
\text { value }\end{array}$ \\
\hline \multirow{2}{*}{$\begin{array}{l}\text { Dewormed } \\
\text { animal }\end{array}$} & Yes & 298 & 259 & 1205 & 500 & \multirow[t]{2}{*}{0.000} & 103 & 377 & 0 & \multirow[t]{2}{*}{0.018} & 6 & 2 & 0 & \multirow[t]{2}{*}{0.773} \\
\hline & No & 297 & 236 & 680 & 300 & & 140 & 245 & 0 & & 7 & 2 & 0 & \\
\hline \multirow{4}{*}{$\begin{array}{l}\text { Anthelmintic } \\
\text { used }\end{array}$} & Fenbendazole & 207 & 184 & 1385 & 600 & \multirow[t]{4}{*}{0.016} & 74 & 290 & 0 & \multirow[t]{4}{*}{0.251} & 6 & 2 & 0 & \multirow[t]{4}{*}{0.448} \\
\hline & Ivermectin & 28 & 26 & 1238 & 375 & & 9 & 1293 & 0 & & 0 & 0 & 0 & \\
\hline & Levamisole & 54 & 40 & 594 & 350 & & 19 & 286 & 0 & & 0 & 0 & 0 & \\
\hline & Natural med. & 8 & 8 & 669 & 550 & & 0 & 0 & 0 & & 0 & 0 & 0 & \\
\hline \multirow{3}{*}{$\begin{array}{l}\text { Last } \\
\text { deworming }\end{array}$} & $<45$ days & 138 & 118 & 1537 & 550 & \multirow[t]{3}{*}{0.000} & 38 & 342 & 0 & \multirow[t]{3}{*}{0.007} & 0 & 0 & 0 & \multirow[t]{3}{*}{0.085} \\
\hline & $46-120$ days & 160 & 141 & 918 & 500 & & 65 & 407 & 0 & & 6 & 3 & 0 & \\
\hline & > 120 days & 297 & 236 & 680 & 300 & & 140 & 245 & 0 & & 7 & 2 & 0 & \\
\hline \multirow[t]{2}{*}{ Sex } & Female & 368 & 308 & 932 & 350 & \multirow[t]{2}{*}{0.676} & 143 & 237 & 0 & \multirow[t]{2}{*}{0.053} & 8 & 1 & 0 & \multirow[t]{2}{*}{0.968} \\
\hline & Male & 227 & 187 & 961 & 400 & & 100 & 430 & 0 & & 5 & 2 & 0 & \\
\hline \multirow{6}{*}{$\begin{array}{l}\text { Productive } \\
\text { stage }\end{array}$} & Lambs & 134 & 102 & 1074 & 275 & \multirow[t]{6}{*}{0.306} & 56 & 274 & 0 & \multirow[t]{6}{*}{0.000} & 0 & 0 & 0 & \multirow[t]{6}{*}{0.029} \\
\hline & $\begin{array}{l}\text { Rearing } \\
\text { lambs }\end{array}$ & 201 & 174 & 911 & 450 & & 101 & 488 & 50 & & 9 & 4 & 0 & \\
\hline & $\begin{array}{l}\text { Pregnant } \\
\text { ewes }\end{array}$ & 64 & 55 & 604 & 350 & & 16 & 65 & 0 & & 1 & 1 & 0 & \\
\hline & $\begin{array}{l}\text { Lactating } \\
\text { ewes }\end{array}$ & 98 & 82 & 1165 & 400 & & 39 & 307 & 0 & & 1 & 1 & 0 & \\
\hline & Empty ewes & 33 & 28 & 867 & 400 & & 8 & 62 & 0 & & 2 & 3 & 0 & \\
\hline & $\begin{array}{l}\text { Breeding } \\
\text { male }\end{array}$ & 65 & 54 & 805 & 350 & & 23 & 215 & 0 & & 0 & 0 & 0 & \\
\hline \multirow[t]{2}{*}{ Breed } & OPC & 303 & 243 & 729 & 300 & \multirow[t]{2}{*}{0.041} & 136 & 216 & 0 & \multirow[t]{2}{*}{0.070} & 9 & 3 & 0 & \multirow[t]{2}{*}{0.137} \\
\hline & Non OPC & 292 & 252 & 1147 & 450 & & 108 & 401 & 0 & & 4 & 1 & 0 & \\
\hline
\end{tabular}

\section{Clinical Factors Associated With Gin Burden In Sheep}

The parasite burden of the sheep studied was related to clinical parameters, including body condition, weight, heart rate, respiratory rate, temperature, hematocrit and FAMACHA® score. Strongylida nematode burden was associated with sheep body condition, hematocrit and FAMACHA® score, while Strongyloides spp. parasite burden was associated with body condition and hematocrit; Trichuris spp. parasite burdens were not associated with any of the variables studied (Table 5). 
Table 5

Clinical factors associated with Strongylida, Strongyloides spp. and Trichuris spp. burdens in sheep in the department of Córdoba.

\begin{tabular}{|c|c|c|c|c|c|c|c|c|c|c|c|c|c|c|}
\hline \multirow[t]{2}{*}{ Variable } & \multirow[t]{2}{*}{ Category } & \multirow[t]{2}{*}{$n$} & \multicolumn{4}{|c|}{ Strongylida } & \multicolumn{4}{|c|}{ Strongyloides spp. } & \multicolumn{4}{|c|}{ Trichuris spp. } \\
\hline & & & Pos. & $\begin{array}{l}\text { Mean } \\
(E P G)\end{array}$ & $\begin{array}{l}\text { Med. } \\
\text { (EPG) }\end{array}$ & $\begin{array}{l}\mathrm{p}- \\
\text { value }\end{array}$ & Pos. & $\begin{array}{l}\text { Mean } \\
\text { (EPG) }\end{array}$ & $\begin{array}{l}\text { Med. } \\
\text { (EPG) }\end{array}$ & $\begin{array}{l}\mathrm{p}- \\
\text { value }\end{array}$ & Pos. & $\begin{array}{l}\text { Mean } \\
\text { (EPG) }\end{array}$ & $\begin{array}{l}\text { Med. } \\
(E P G)\end{array}$ & $\begin{array}{l}\mathrm{p}- \\
\text { value }\end{array}$ \\
\hline \multirow{3}{*}{$\begin{array}{l}\text { Body } \\
\text { condition }\end{array}$} & Good & 178 & 141 & 694 & 300 & \multirow[t]{3}{*}{0.018} & 66 & 220 & 0 & \multirow[t]{3}{*}{0.022} & 3 & 1 & 0 & \multirow[t]{3}{*}{0.324} \\
\hline & Average & 296 & 252 & 984 & 500 & & 136 & 402 & 0 & & 9 & 2 & 0 & \\
\hline & Bad & 120 & 101 & 1208 & 400 & & 41 & 224 & 0 & & 1 & 0 & 0 & \\
\hline \multirow[t]{3}{*}{ Hcrit. } & High & 149 & 130 & 650 & 350 & \multirow[t]{3}{*}{0.001} & 57 & 201 & 0 & \multirow[t]{3}{*}{0.028} & 0 & 0 & 0 & \multirow[t]{3}{*}{0.056} \\
\hline & Average & 294 & 231 & 808 & 300 & & 113 & 327 & 0 & & 7 & 2 & 0 & \\
\hline & Low & 147 & 129 & 1514 & 500 & & 71 & 391 & 0 & & 6 & 3 & 0 & \\
\hline \multirow[t]{5}{*}{ Famacha ${ }^{\circledR}$} & 1 & 38 & 30 & 499 & 200 & \multirow[t]{5}{*}{0.000} & 15 & 116 & 0 & \multirow[t]{5}{*}{0.526} & 1 & 4 & 0 & \multirow[t]{5}{*}{0.555} \\
\hline & 2 & 242 & 197 & 607 & 300 & & 95 & 290 & 0 & & 5 & 2 & 0 & \\
\hline & 3 & 216 & 181 & 841 & 400 & & 85 & 290 & 0 & & 3 & 1 & 0 & \\
\hline & 4 & 90 & 78 & 1685 & 600 & & 45 & 443 & 25 & & 4 & 3 & 0 & \\
\hline & 5 & 9 & 9 & 6867 & 5500 & & 3 & 872 & 0 & & 0 & 0 & 0 & \\
\hline
\end{tabular}

n: Number of observations; Pos.: Positives; EPG: Eggs per gram; Med.: Median; Hcrit.: Hematocrit

\section{Geographical Factors Associated With Gin Burden In Sheep}

An epidemiological map was generated using the kernel density estimator, which depicts the association between parasite burdens and their distribution between regions and municipalities in the department of Córdoba (Fig. 1). The map shows the location of the farms evaluated with their respective GIN prevalence. Several high-density clusters can be observed; the first one is located between Sinú Medio and Sinú Bajo regions and extends towards the north of the Sabana region, the second one in the San Jorge region. The municipalities with the highest parasite burdens were Purísima, Lorica, Cereté, San Carlos, Puerto Libertador and San José de Uré, which are located in regions with high-density clusters.

\section{Genera Of Nematodes Identified}

In the farms studied, a 100\% prevalence was identified for the genus Trichostrongylus spp., 78.3\% for Strongyloides spp., 76.7\% for Haemonchus spp., $53.3 \%$ for Oesophagostomum spp., $10 \%$ for Bunostomun spp. and 1.7\% for Cooperia spp. The results of the faecal culture and the percentage of infective larvae in each genus are presented in Table 6.

Table 6

Infective larvae prevalence and percentages of the nematode genera identified in sheep farms in the department of Córdoba.

\begin{tabular}{|llll|}
\hline Genus & Farms & Prevalence per farm (\%) & Infective larvae percentage (L3) \pm SD \\
\hline Trichostrongylus spp. & 60 & 100 & $52,0 \pm 21$ \\
\hline Strongyloides spp. & 47 & 78,33 & $18,6 \pm 16,5$ \\
\hline Haemonchus spp. & 46 & 76,67 & $17,4 \pm 16$ \\
\hline Oesophagostom spp. & 32 & 53,33 & $11,4 \pm 16$ \\
\hline Bunostomun spp. & 6 & 10,0 & $0,5 \pm 1,7$ \\
\hline Cooperia spp. & 1 & 1,67 & $0,1 \pm 0,5$ \\
\hline Obs.: Number of observations; Pos.: Positives; Sd.: Standard deviation; Med.: Median.
\end{tabular}

\section{Discussion}


The results of this study reveal a serious situation of GIN parasitism in sheep farms in the department of Córdoba. All of the farms sampled showed cases of gastrointestinal parasitism, where $88.6 \%$ of the animals were affected with one or more types of nematodes. Although parasitic infection was expected due to an apparent predisposition of the sheep, it is important to note that the seriousness of this finding lies not only in the prevalence of parasitism but also in the high parasite burdens, which averaged $1255 \mathrm{EPG} /$ animal; this value is considered a high-level infection, taking into account the classification of infection levels according to Hansen and Perry (1994). Considering the parasitic groups, high-level infections were found to be caused by Strongylida nematodes, mostly from the Trichostrongylidae family, which harbors genera of importance in sheep due to their high pathogenicity such as Haemonchus contortus (Wang et al. 2020) and whose parasitic burdens in this study showed a significant association with clinical factors such as body condition, hematocrit and FAMACHA score. Strongyloides spp. infections were considered moderate and Trichuris spp. infections low.

Dewormed animals and those with recent deworming before McMaster tests, presented the highest Strongylida and Strongyloides spp. burdens; this contradictory situation may be explained as a desperate need of producers to apply anthelmintics due to the inefficient reduction of parasite burdens; in the study, we observed that different farms performed monthly application of anthelmintics; these results suggest signs of anthelmintic resistance, especially related to the infections due to Strongylida nematodes.

Regardless of the type of anthelmintic used, parasite burdens were high, suggesting a possible inefficiency of fenbendazole, ivermectin, levamisole and the use of natural medicine in the control of parasitism. It should be noted that in the overall count and the Strongylida order, lower burdens were found in sheep that had been treated with levamisole. The development of anthelmintic resistance, especially to ivermectin and fenbendazole, has been previously reported in several studies (Torres-Acosta et al. 2012). This result reflects the need to implement monitoring programs to assess the efficacy of anthelmintics used in the parasitic control of sheep.

The degree of infection by Trichuris spp. did not differ according to the type of anthelmintic used; it is necessary to point out that burdens of this parasitic group were very low, which cannot suggest the effectiveness of the anthelmintics used since there was also no difference between dewormed and non-dewormed animals and between the time of the last deworming; this result is rather associated with the low prevalence and low burdens of Trichuris spp. in the department of Córdoba.

The GIN infection prevalence and parasite burdens were similar in males and females. Most studies address the influence of sex on GIP prevalence and in general, there is no consensus on which sex is more affected (Poddar et al. 2017).

Productive stage was not associated with overall parasite burdens or Strongylida infections. However, there is a trend of higher burdens in rearing animals and lactating ewes. In that sense, several studies agree that young animals are more susceptible to gastrointestinal parasitism (Raza et al. 2007) since they have an immune system with insufficient development to modulate parasitic infestation (Khan et al. 2010); on the other hand, it is known that regardless of the year, season and age, ewes present greater susceptibility to GIN during lactation (González-Garduño et al. 2014). Experimentally, there are studies that support the hypothesis that full grown animals can acquire immunity against GIN (Knox 2000). Regarding the degree of infection, Ensuncho et al. (2014) reported that lactating animals and lactating ewes presented the highest parasite burdens.

Breed was associated with overall GIN parasite burden and particularly for Strongylida and Strongyloides spp. nematodes. It was observed that breeds belonging to OPC had lower parasite burdens. Breeding studies of small ruminants have revealed a reduction of EPG in faeces when animals that are naturally resistant to GIN infection are selected for breeding (Eady et al. 1996). Genetic factors are known to contribute to the ability of sheep to cope with the challenge of intestinal parasitism; some studies have shown that different breeds of sheep exhibit varying resistance to intestinal parasite infection (Aboshady et al. 2020). In particular, Preston and Allonby (1979) demonstrated an ascending order of susceptibility in the Red Masai, Blackhead Persian, Merino, Dorper, Corriedale and Hampshire breeds. However, other undesirable traits, especially in terms of productivity, could make parasitism-resistant breeds unattractive to producers (Woolaston and Baker 1996). In this regard more recent studies, have shown that genome-wide selection strategies can improve selection of animals with a view on production aspects and helminthiasis resistance traits (McManus et al. 2014).

The clinical variables analyzed, namely: body condition, hematocrit and FAMACHA® result, were especially related to high parasite burdens by Strongylida. Animals with the highest degrees of infection showed fair or poor body condition, low hematocrit values and higher FAMACHA ${ }^{\circ}$ results. For Strongylida nematodes, the FAMACHA® method had a better predictive value, followed by hematocrit and body condition; Strongyloides spp. infections were correlated only with hematocrit and body condition. The above allows to state that the alteration of the clinical variables and their use as predictive value of the parasitic burden, will depend on the parasitic group that is affecting the animals.

The most prevalent nematode genera are associated with the percentage of larvae identified from the faecal cultures. Trichostrongylus spp., Strongyloides spp. and Haemonchus spp. were the most prevalent genera in sheep in the department of Córdoba. These have been previously reported (Ensuncho et al. 2014). It is important to highlight, that it was found for the first time for the department of Córdoba, Bunostomum spp. nematodes comprising GIN infections in sheep. Although they were only identified in $10 \%$ of the flocks studied, their hematophagous behavior, as well as that of $\mathrm{H}$. contortus, causes a decrease in hematological values, including hemoglobin, with immediate consequences such as hypoproteinemia and a decrease in body condition. Analyzing these clinical aspects is important when making decisions regarding deworming management in sheep production systems; Besier et al. (2016) indicate that a good body condition may indicate the ability of sheep to better cope

Page $8 / 11$ 
with parasitism. Increasing resistance to anthelmintics has resulted in developing deworming management alternatives, which reduce the selection resistant parasites, being essential. In this regard, a suitable approach would be to treat only those animals that are unable to cope with the parasite challenge.

The clinical evaluation of anemia using the FAMACHA® system and the body condition of the animals are two important clinical aspects to examine a flock and identify animals that do require anthelmintic treatment (Van Wyk and Bath 2002), these selective deworming programs could be considered within the strategies implemented in the flocks to delay the development of resistance. In the present study, it is evident that the FAMACHA® Method and the measurement of body condition can be used to establish selective deworming programs in herds in the department of Córdoba, since a significant association with parasite burden was found.

Gastrointestinal parasitism in sheep is a worldwide issue, which requires a deeper understanding of epidemiological aspects such as prevalence, distribution and seasonal patterns of transmission in different climatic zones. There is a strong belief that climate change may alter the geographical distribution of parasites and their impact on hosts, a situation that is also attributed to the phenomenon of resistance (Chalier et al. 2014). It is believed, that climatic changes would have profound effects on the epidemiology of parasites, especially for those, whose developments outside the definitive host are sensitive to temperature and humidity linked to rainfall. The influence of environmental conditions is particularly evident in spatial distribution studies that allow the visualization of clusters where animals show not only the prevalence of gastrointestinal parasitism, but also high levels of infection, a parameter that is very interesting to predict the damage caused to individuals and the economic losses of the producer.

The results of this study reveal a serious situation of gastrointestinal parasitism in sheep production systems in the department of Córdoba. All the farms studied are infected by gastrointestinal nematodes; however, the identification of two high density clusters allows directing epidemiological and control studies to these areas. The results suggest a possible resistance to anthelmintics used by the producers, a situation that requires further evaluation.

\section{Declarations}

Acknowledgements The authors are grateful to all farmers who generously gave their time and hospitality to fulfill this study.

Author contribution Elisa Brunal Tachack

- Performing the field and laboratory testing activities, and writing up the manuscript

Teresa Oviedo-Socarrás

- Leading the study, acquiring funding, managing the field sample collection activities, and writing up the manuscript.

Misael Oviedo Pastrana

- Managing the field sample collection activities, assisting in survey design, managing data analysis and writing up the manuscript. Luis Carlos Pérez-Cogollo

- Assisting in survey design, analyzing the diagnostic laboratory testing and writing up the manuscript.

Yonairo Herrera Benavides

- Assisting in laboratory testing activities, and writing up the manuscript.

Clara Rugeles Pinto

•Acquiring funding, performing the field sample and data collection activities.

Oscar Vergara Garay

- Assisting in survey design, acquiring funding and writing up the manuscript.

Funding This research was funded by Universidad de Córdoba (project number FMV-07-16).

Ethics approval The study was conducted under the rules of conduct for the use of animals in teaching and research and current legislation, it was approved before the data collection process according to Act No.001/18 of the Faculty of Veterinary Medicine and Animal Husbandry Ethics Committee of Universidad de Córdoba.

Data availability The datasets generated during the current study are available from the corresponding author on reasonable request.

Conflict of Interest The authors declare no competing interests. 


\section{References}

1. Aboshady, H.M., Stear, M.J., Johansson, A., Jonas, E, Bambou, J.C., 2020. Immunoglobulins as Biomarkers for Gastrointestinal Nematodes Resistance in Small Ruminants: A systematic review. Scientific Reports, 10, 7765.

2. Al-Shaibani, I.R.M., Phulan, M.S., Arijo, A., Qureshi, T.A., 2008. Epidemiology of ovine gastrointestinal nematodes in Hyderabad district, Pakistan. Pakistan Veterinary Journal, 28, 125-130.

3. Besier, R.B., Kahn, L.P., Sargison, N.D., Van Wyk, J.A., 2016. Diagnosis, treatment and management of Haemonchus contortus in small ruminants. Advances in Parasitology, 93, 181-238.

4. Charlier, J., Van der Voort, M., Kenyon, F., Skuce, P., Vercruysse, J., 2014. Chasing helminths and their economic impact on farmed ruminants. Trends in Parasitology, 30, 361-367.

5. Corticelli, B. and Lai, M., 1963. Ricerche sulla tecnica di coltura delle larve infestive degli strongili gastro-intestinali del bovino. Acta Medica Veterinaria, 9, 347-357.

6. Eady, S.J., Woolaston, R.R., Mortimer, S.I., Lewer, R.P., Raadsma, H.W., Swan, A.A., Ponzoni, R.W., 1996. Resistance to nematode parasites in Merino sheep: sources of genetic variation. Australian Journal of Agricultural Research, 47, 895-915.

7. Ensuncho, H.C., Castellano, C.A., Maza, A.L., Bustamante, Y.M., Vergara, G.O., 2014. Prevalencia y grado de infección de nemátodos gastrointestinales en ovinos de pelo en pastoreo de cuatro municipios de Córdoba, Colombia. Revista Científica, FCV-LUZ, 24, 414-420.

8. González-Garduño, R., Torres-Acosta, J.F.J., Chay-Canul, A.J., 2014. Susceptibility of hair sheep ewes to nematode parasitism during pregnancy and lactation in a selective anthelmintic treatment scheme under tropical conditions. Research in Veterinary Science, 96, 487-92.

9. Hansen, J. and Perry, B., 1994. The Epidemiology, Diagnosis and Control of Helminth Parasites of Ruminants: A Handbook, (International Livestock Research Institute, Nairobi).

10. Herrera, L., Ríos, L., Zapata, R., 2013. Frecuencia de la infección por nemátodos gastrointestinales en ovinos y caprinos de cinco municipios de Antioquia. Revista MVZ Córdoba, 18, 3851-3860.

11. Kaplan, R.M., Biology, 2020. Epidemiology, Diagnosis, and Management of Anthelmintic Resistance in Gastrointestinal Nematodes of Livestock. The Veterinary Clinics of North America. Food Animal Practice, 36, 17-30.

12. Kaplan, R.M. and Vidyashankar, A.N., 2012. An inconvenient truth: global worming and anthelmintic resistance. Veterinary Parasitology, 186, 70-78.

13. Keyyu, J.D., Kyvsgaard, N.C., Monrad, J., Kassuku, A.A., 2005. Epidemiology of gastrointestinal nematodes in cattle on traditional, small-scale dairy and large-scale dairy farms in Iringa district, Tanzania. Veterinary Parasitology, 127, 285-294.

14. Khan, M.N., Sajid, M.S., Khan, M.K., Iqbal, Z., Hussain, A., 2010. Gastrointestinal helminthiasis: prevalence and associated determinants in domestic ruminants of district Toba Tek Singh, Punjab, Pakistan. Parasitology Research, 107, 787-794.

15. Knox, D.P., 2000. Development of vaccines against gastrointestinal nematodes. Parasitology, 120, $43-61$.

16. McManus, C., Do Prado, P.T., De Melo, C.B., Brasil, B.S., Paiva, S.R., 2014. Selection methods for resistance to and tolerance of helminths in livestock. Parasite, 21, 56

17. Poddar, P.R., Begum, N., Alim, M.A., Dey, A.R., Hossain, M.S., Labony, S.S., 2017. Prevalence of gastrointestinal helminths of sheep in Sherpur, Bangladesh. Journal of Advanced Veterinary and Animal Research, 4, 274-280.

18. Preston, J.M. and Allonby, E.W., 1979. The influence of breed on the susceptibility of sheep to Haemonchus contortus infection in Kenya. Research in Veterinary Science, 26, 134-139.

19. Pulido-Medellín, M.O., García-Corredor, D., Díaz-Anaya, A., Andrade-Becerra, R., 2014. Pesquisa de parásitos gastrointestinales en pequeñas explotaciones ovinas del municipio de Toca, Colombia. Revista de Salud Animal, 36, 65-69.

20. Raza, M.A., Iqbal, Z., Jabbar, A., Yaseen, M., 2007. Point prevalence of gastrointestinal helminthiasis in ruminants in southern Punjab, Pakistan Journal of Helminthology, 81, 323-328.

21. Torres-Acosta, J.F.J, Mendoza-De Gives, P., Aguilar-Caballero, A.J., Cuellar-Ordaz, J.A., 2012. Anthelmintic resistance in sheep farms: update of the situation in the American continent. Veterinary Parasitology, 189, 89-96.

22. Van Wyk, J.A. and Bath, G.F., 2002. The FAMACHA@ system for managing haemonchosis in sheep and goats by clinically identifying individual animals for treatment. Veterinary Research, 33, 509-529.

23. Van Wyk, J.A., Cabaret, J., Michael, L.M., 2004. Morphological identification of nematode larvae of small ruminants and cattle simplified. Veterinary Parasitology, 119, 277-306.

24. Wang, T., Ma, G., Ang, C-S., Korhonen, P.K., Stroehlein, A.J., Young, N.D., Hofmann, A., Chang, B.C.H., Williamson, N.A., Gasser, R.B., 2020. The developmental phosphoproteome of Haemonchus contortus. Journal of Proteomics, 213, 103615.

25. Woolaston, R.R. and Baker, R.L., 1996. Prospects of breeding small ruminants for resistance to internal parasites. International Journal for Parasitology, 26, 845-855. 
26. Zajac, A.M. and Garza, J., 2020. Biology, Epidemiology, and Control of Gastrointestinal Nematodes of Small Ruminants. Veterinary Clinics: Food Animal Practice, 36, 73-87.

\section{Figures}

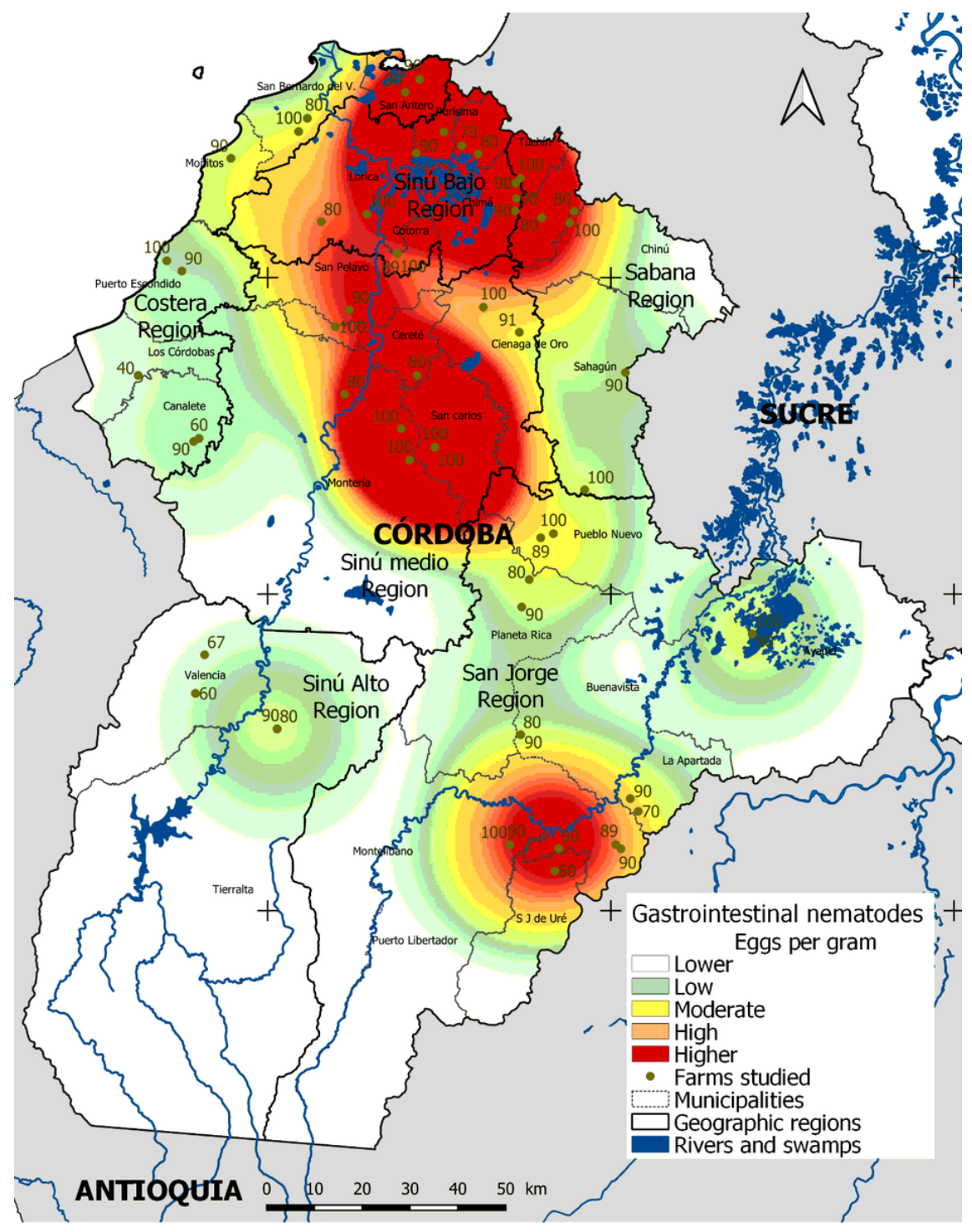

Figure 1

Epidemiological map of gastrointestinal nematode infection prevalence and burden in sheep in the department of Córdoba. Categorization is shown using standard deviation over the mean of the data represented. 